\title{
韓国・外羅老島の日本人移住漁村の居住空間構成とその変容 \\ SPATIAL FORMATION AND TRANSFORMATION OF HOUSES IN JAPANESE MIGRANT FISHING VILLAGE COLONY IN OENARO-DO, KOREA
}

\author{
朴 重 信*，金 泰 永**，李勲***，布野修司**** \\ Chungshin PARK, Taiyoung KIM, Hoon YI \\ and Shuji FUNO
}

\begin{abstract}
This paper aims to clarify spatial formation and transformation of Japanese migrant fishing village the colonial period of Korea in Oenaro-do Island. The fishing village in Oenaro-do is shaped in the unique topographical structure, where river meets the sea at right angle. Consequently, the village was formed into "L" shape. The web of road is composed of three basic types of street, present coastal street, inner old coastal street parallel to the present one and perpendicular alley connecting these two roads together. According to these street pattern, plots of land in the block are formed into distinctive trapezoidal shape.

Taking notice of spans in the width of building, it can be classified into one bay type, two bay type and, multiple bay type. Typical model are one bay type and two bay type. Generally, one bay type and two bay type have rectangular spatial configuration simply composed of shop, kitchen and residence respectively.

Due to narrow frontage, transformation can be observed in the unification of building which can be classified into horizontal (depth) and vertical (width) unification. Horizontal unification is achieved by combination of two buildings in the row which use the same partition wall, while vertical unification is attained by combination of narrow width of two buildings in each rear wall.
\end{abstract}

Keywords: Japanese migrant fishing village,(Nissiki Jutaku)Japanese Style House, Spatial Formation, Transformation, Oenaro-do 日本人移住漁村、日式住宅、空間構成、变容, 外羅老島

1. はじめに

\section{1-1 研究の目的と意菨}

本稿は、「日本植民地期における韓国の日本人移住漁村の形成と変容 に関する研究」*1 の一環として、外羅老島の日本人移住漁村を対象とし、 居住空間構成とその変容について考察することを目的とする。

前稿では、日本人の韓国移住の背景とその形成過程を考察し、巨文島 の巨文港を取り上げ、その形成過程と空閒構成を明らかにした上で、古 式住宅の空間構成と変容について考察しだ。

1903年から始まった日本人の外羅老島への移住に関する文献は、他の 漁村と比べると非常に少ない。主要な参考文献は末尾に示す通りである*4。 また、日本人移住漁村と日式住宅に関する文献は、前稿にまとめる通りで ある*5。

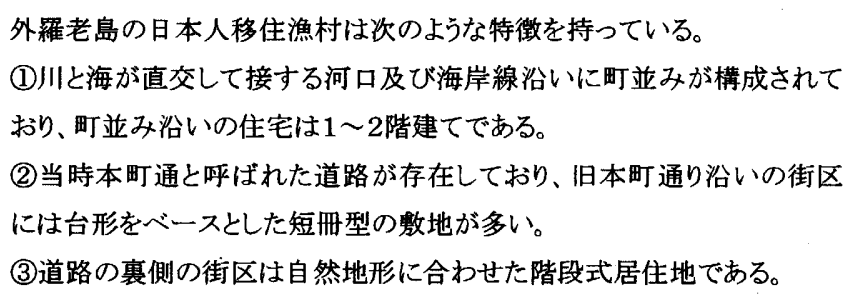
道路の幅、町並みなど居住地の構成は当時の状態のままである。

* 京都大学大学院工学研究科 工博

** 韓国清州大学建築工学部建築学専攻 教授·工博

*** 韓国忠北大学建築学科 教授 · 工博

**** 滋賀県立大学大学院環境科学研究科教授 ·工博 Dr. Eng.
それ故、本稿では旧本町通沿いの短冊型の住宅を対象とし、居住空間 構成と解放後のその変容特性に焦点を当てる。これらを解明することによっ て、日韓両国の居住文化の比較と居住文化の地域性を解明するに当って 重要な手がかりが得られる。

\section{1-2 調査概要}

本稿は四次にわたる現地調查を基にして いる。第1次調查(2004年2月22日)では、現状 確認と写真撮影を行い、第2 次調查(2004年6 月17日)では、地籍図、航空写真、地形図など の資料収集を行うとともに集落の変遷過程に 関するヒアリング調查を行った。第 3 次調查 (2004年6月28日)では、前2回の調查を踏まえ た上で島の全域の住居分布と建築類型の悉 皆調查を行い、旧本町通沿いの住宅を調查 対象として選定した。第4次調查(2004年7月 5 日〜8日)では、選定した住宅の実測調查を行 った。実測の内容としては、まず旧本町通り沿

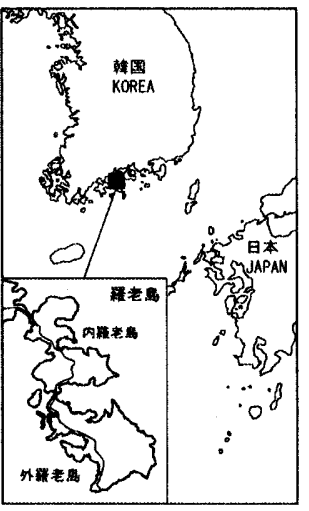
い*6 の住宅の88棟"7 を対象として建物外周とエ レベーションを害測した上でその内 55 棟の間取りを調查した。さらに55棟の 中で代表的な事例を14棟選び、平面、立面、断面を詳細に実測した*8。

Dept. of Architecture and Architectural Engineering, Kyoto University, Dr. Eng. Prof., Dept. of Architecture and Environmental Design, Cheongju University,

Prof., Dept. of Architectural Design, Chungbuk University, Dr. Eng.

Prof., Graduate School of Environmental Science, The University of Shiga Prefecture, Dr. Eng. 


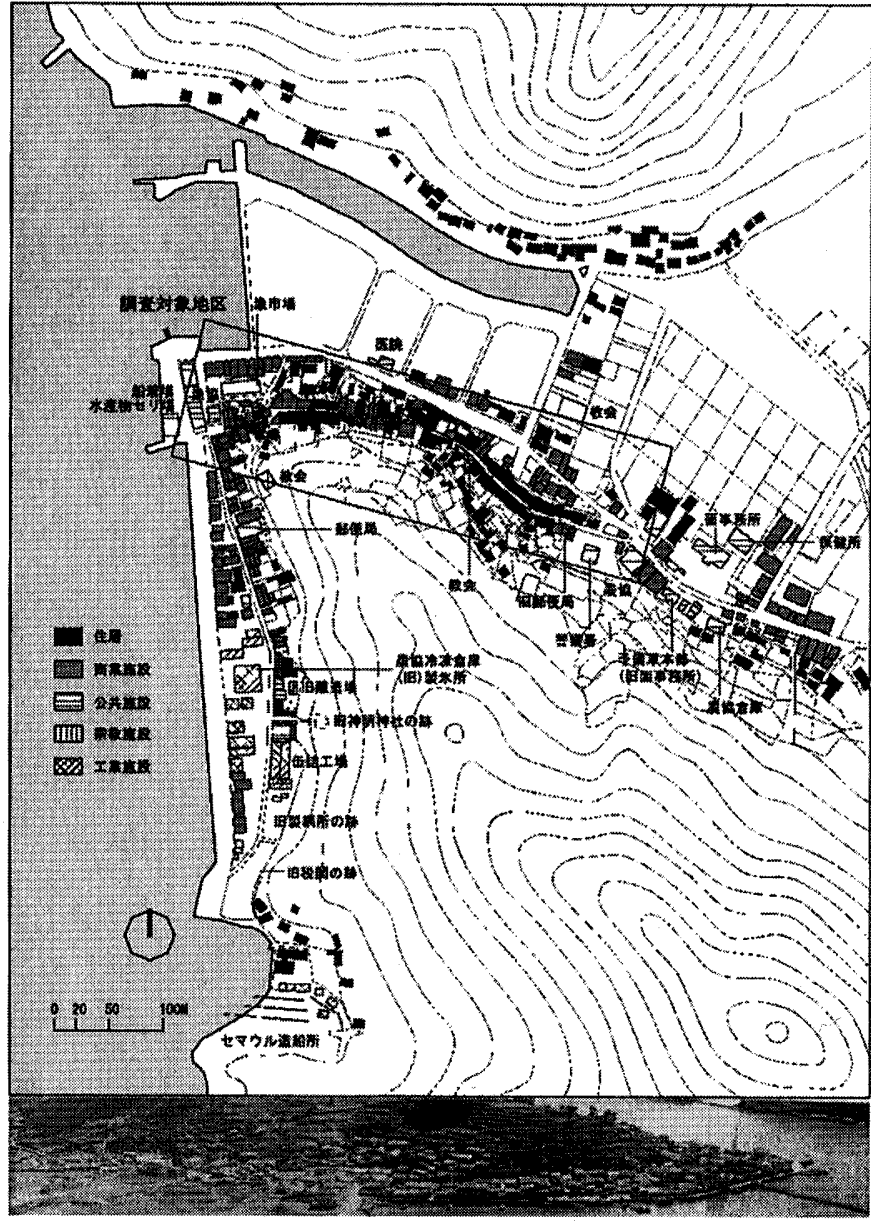

图2 外羅老島の施設分布と1930年代の集落

外羅老岛全体の構成概要は図 2 に示寸通りである。調查対象住宅は表 1及び図4に示す。

\section{2. 外羅老島の日本人移住漁村 \\ 2-1 外羅老島の概要}

羅老岛は韓半島の南端に位置し、内羅老岛と外羅老島の2つの島で構 成されている。本来この地域は逢莱 (ボンレ)*9 と言い、朝鮮時代の記録を みると当時道陽牧場の属場*10であった。一方、羅老島という地名の語源を 探ってみると次のようである。羅老島(ナロド)は朝鮮時代に国に馬を提供す る島である意味で国島(クックド)と記され、これを韓国語で発音すると「ナラ ソム」むしくは「ナラド」という。これを日本人が移住してこの発音を漢字に表 記する祭に「羅老島」*11 とした。

現在、韓国南海の主要漁港の一つであり、1966年には漁業前進基地 ${ }^{* 12}$ として指定されている。典型的な主漁従農村として、主要産物は海老など の甲殼類、鰻·鯛·鰆・太刀魚などの魚類、海苔、若芽などの海藻類であり、 釜山、麗水、木浦、巨文島、済州島をつなぐ海運の要衝でもある。娚查対 象地区である築亭(チュクジョン)1・2区は2つの小さい島に井まれており、 避難港としても適しており、天然の良港となっている。また、当時から製水 工場と製網工場、造船所が位置し、韓国で2番目に大きい缶詰工場もあっ た。現在でも羅老島の特産物であるサワラ波市 ${ }^{* 13}$ が全国的に有名である。

\section{2-2 外羅老島の漁村菓落の立地と地形}

日本人移住漁村を立地別に区分すると、湾型、前島型、河川型の3つに 分けられる ${ }^{14}$ 。湾型は天然の湾に形成される集落であり、前島型は海岸に 隣接して島があって、その間に形成された集落である。そして、河川型は海
表1 調查対象の概要

\begin{tabular}{|c|c|c|c|c|c|c|c|}
\hline 記号 & 番地 & $\begin{array}{l}\text { 建宓 } \\
\text { 年代 }\end{array}$ & 用途 & $\begin{array}{c}\text { 間口 } \\
(\mathrm{m})\end{array}$ & $\begin{array}{l}\frac{6}{6} \text { 奥行 } \\
(\mathrm{m})\end{array}$ & $\begin{array}{l}\text { 秧造 } \\
\text { 階数 }\end{array}$ & $\begin{array}{c}\text { 建究面䅡 } \\
\left(\mathrm{m}^{2}\right)\end{array}$ \\
\hline S01 & 1073 & 1957 & 娛楽室/住宅 & 11.90 & 12.36 & $\mathrm{~W} / 1$ & 97.89 \\
\hline S02 & $1069-1$ & 1992 & 尃用住宅 & 8.10 & 14.40 & $\mathrm{~B} / 1$ & 148.80 \\
\hline S03 & $1069-7$ & 1943 & 専角集宅 & 6.40 & 7.45 & W/1 & 40.60 \\
\hline S04 & $1068-6$ & 1941 & 空家 & 16.80 & 9.10 & $\mathrm{~W} / 1, \mathrm{~B}$ & 89.20 \\
\hline S05 & $1068-5$ & 1997 & 專苚住宅 & 8.54 & 9.83 & $B / 1$ & 58.47 \\
\hline S06 & $1068-4$ & 1984 & 空き店舖/住宅 & 4.91 & 10.82 & $\mathrm{~B} / 1$ & 39.60 \\
\hline S07 & $1068-2$ & 1978 & 専角住宅 & 7.18 & 11.85 & $\mathrm{~B} / 1$ & 66.10 \\
\hline S08 & $1068-1$ & 1973 & 専用住宅 & 11.34 & 10.99 & $\mathrm{~B} / 2$ & 171.60 \\
\hline 509 & $1044-2$ & 1943 & 荨用崔宅 & 4.67 & 7.44 & $\mathrm{~B} / 2$ & 48.58 \\
\hline $\mathrm{S10}$ & 1033 & 1943 & 食堂/住宅 & 13.02 & 12.60 & $\mathrm{~B} / 1$ & 165.30 \\
\hline S11 & 1028 & 1943 & 専用住宅 & 12.09 & 9.05 & $\mathrm{~W} / 1$ & 74.38 \\
\hline $\mathrm{S} 12$ & $1027-2$ & 1982 & 雑貨店/住宅 & 9.52 & 8.30 & $\mathrm{~B} / 2$ & 79.40 \\
\hline $\mathrm{S13}$ & 1024 & 1943 & 軍用住宅 & 10.10 & 8.35 & $\mathrm{~W} / 2, \mathrm{~B}$ & 111.30 \\
\hline S14 & 1023 & 1943 & 洗潍屋/住宅 & 9.06 & 15.04 & $\mathrm{~W} / 2, \mathrm{~B}$ & 39.00 \\
\hline S15 & 1020 & 1993 & 荨角住宅 & 4.15 & 10.87 & $\mathrm{~B} / 2$ & 60.48 \\
\hline S16 & $1020-2$ & 1943 & 専用住宅 & 5.84 & 11.02 & $\mathrm{~W} / 1$ & 54.20 \\
\hline S17 & 1005 & 1981 & 専角住宅 & 4.32 & 17.00 & $\mathrm{~W} / 1$ & 112.00 \\
\hline $\mathrm{S} 18$ & 1006 & 1960 & 空き店荶/住宅 & 4.43 & 12.72 & $\mathrm{~W} / 1$ & 56.19 \\
\hline S19 & 1007 & 1970 & 空き店舖/住宅 & 4.08 & 16.52 & $\mathrm{~W} / 1$ & 50.24 \\
\hline S20 & 1010 & 1970 & 専用住宅 & 4.26 & 15.65 & $\mathrm{~W} / 1$ & 46.20 \\
\hline S21 & 1000 & 1965 & 空き店舖/住宅 & 14.81 & 14.99 & $\mathrm{~W} / 1$ & 162.00 \\
\hline S22 & $999-1$ & 1945 & 菜局/住宅 & 14.87 & 13.43 & $\mathrm{~W} / 2$ & 157.00 \\
\hline $\mathrm{S} 23$ & $998-2$ & 1973 & 賈金融厔/住宅 & 6.80 & 6.50 & $\mathrm{~B} / 2$ & 39.70 \\
\hline \$24 & $996-6$ & - & 美容室/住宅 & 7.76 & 12.24 & $\mathrm{~B} / 2$ & 186.00 \\
\hline S25 & $999-3 / 5 / 7$ & - & 船真店/住宅 & 5.70 & 10.60 & $\mathrm{~B} / 2$ & - \\
\hline S26 & $1000-1$ & 1956 & 魚屋·食堂/住宅 & 20.05 & 23.45 & $\mathrm{~W} / 2$ & 541.17 \\
\hline N01 & $1089-30$ & 1974 & 専角住宅 & 3.34 & 4.65 & $\mathrm{~B} / 1$ & 46.00 \\
\hline N02 & $1089-12$ & 1975 & 専用住宅 & 5.54 & 9.54 & $\mathrm{~B} / 1$ & 36.36 \\
\hline N03 & $1089-28 / 29$ & 1943 & 専用住宅 & 9.33 & 5.96 & $\mathrm{~W} / 1$ & 96.19 \\
\hline N04 & $1089-27$ & 1941 & 専用住宅 & 6.95 & 10.80 & $\mathrm{~W} / 1$ & 55.20 \\
\hline N05 & $1089-26$ & 1948 & 専用住宅 & 7.02 & 9.02 & $\mathrm{~W} / 1$ & 36.40 \\
\hline N06 & $1089-24$ & 1970 & 専用住宅 & 6.22 & 10.80 & $\mathrm{~B} / 1$ & 43.20 \\
\hline N07 & $1089-22$ & 1943 & 專用住宅 & 6.70 & 8.45 & $\mathrm{~W} / 1$ & 53.88 \\
\hline N08 & $1089-21$ & 1943 & 専用住宅 & 5.50 & 7.58 & $\mathrm{~W} / 1$ & 46.28 \\
\hline N09 & $1089-19 / 20$ & 1963 & 專用住宅 & 7.35 & 11.30 & $\mathrm{~B} / 1$ & 60.16 \\
\hline N10 & $1089-17$ & 1943 & 専用住宅 & 5.65 & 13.84 & $\mathrm{~B} / 1, \mathrm{~W}$ & 160.30 \\
\hline N11 & $1089-15$ & 1966 & 空家 & 9.34 & 8.15 & $\mathrm{~W} / 2$ & 66.39 \\
\hline $\mathrm{N12}$ & $1041-2 / 3$ & 1978 & 專角住宅 & 8.39 & 7.50 & $\mathrm{~B} / 1, \mathrm{~S}$ & 27.43 \\
\hline N13 & $1040-1 / 1041$ & 1940 & 写真館/住宅 & 8.08 & 18.80 & $\mathrm{C} / 2$ & 138.55 \\
\hline N14 & $1035-11 / 12$ & - & 鉄物倉庫/住䆒 & 4.18 & 9.57 & $\mathrm{~W} / 1$ & - \\
\hline N15 & $1035-7 / 9$ & - & 専用住宅 & 2.75 & 20.85 & $\mathrm{~B} / 1$ & - \\
\hline N16 & 1034 & 1980 & 専用住宅 & 9.60 & 15.32 & $\mathrm{~B} / 1$ & 71.06 \\
\hline N17 & $1029-2 / 3$ & 1943 & 空き店舖/住宅 & 7.27 & 14.69 & $\bar{W} / 1$ & 89.90 \\
\hline N18 & $1026-29$ & 1979 & 文房具屋/住宅 & 4.15 & 19.04 & $\mathrm{~B} / 1$ & 13.30 \\
\hline N19 & $1026-1$ & 1985 & 黨業事務所 & 4.40 & 17.71 & $\mathrm{~B} / 1$ & 27.70 \\
\hline N20 & 1022 & 1935 & パン屋/住宅 & 9.20 & 10.94 & $\mathrm{C} / 2$ & 99.20 \\
\hline N21 & 1021 & 1943 & 鉄物店/住宅 & 6.68 & 15.68 & $\mathrm{~W} / 2$ & 97.00 \\
\hline N22 & 1019 & 1976 & 空き店领/住宅 & 4.11 & 23.74 & $\mathrm{~W} / 2$ & 33.00 \\
\hline $\mathrm{N} 23$ & 1014 & 1943 & 空き店舖/住宅 & 11.07 & 11.20 & $\mathrm{~W} / 1$ & 74.38 \\
\hline $\mathrm{N} 24$ & 1009 & 1977 & 專用住宅 & 4.57 & 9.11 & $\mathrm{~B} / 2$ & 38.34 \\
\hline $\mathrm{N} 25$ & $1003 / 1008$ & 1996 & 美容室/住宅 & 12.86 & 9.16 & $B / 1$ & 49.20 \\
\hline $\mathrm{N} 26$ & $998-11 / 10 / 14$ & 1993 & スーパー/住宅 & 13.31 & 17.46 & $\mathrm{~B} / 1$ & 159.14 \\
\hline $\mathrm{N} 27$ & $1000-2$ & 1980 & 靴屋/住宅 & 6.63 & 7.31 & $\mathrm{~B} / 2$ & 47.43 \\
\hline $\mathrm{N} 28$ & $1000-42$ & 1945 & 空家 & 8.77 & 9.57 & $\mathrm{~W} / 2$ & 49.50 \\
\hline $\mathrm{N} 29$ & $1000-76$ & - & 魚屋/住宅 & 8.31 & 16.8 & $\mathrm{~W} / 1$ & - \\
\hline
\end{tabular}

岸線に湾曲が少なく、河川の河口を中心に形成された集落を言う。

外羅老島の漁村集落は、前島型と河川型が混じった型で、高度100〜 $250 \mathrm{~m}$ の山地を背後にして、山頂から西北に流れる川と海が直交している沿 岸沿いの狭险地に構成されているのが大きな特徴である。また、港湾周辺 の海域の水深が深く、大きな船の出入りが自由にできたため、主要漁港と して成長・発展する背景となったのである。

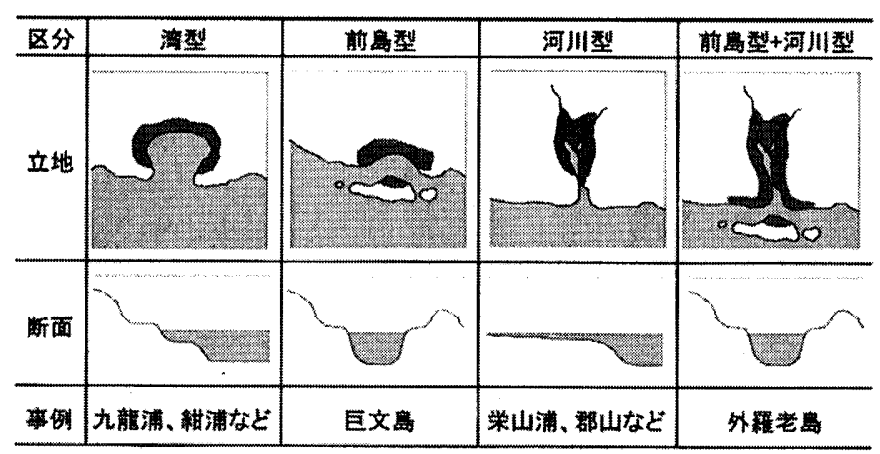

図3 漁村集落の立地別類型 


\section{2-3 日本人移住渙村の形成過程と発展}

記録上、外羅老島で日本人が最初に漁業を始めたのは 1894 年となって いる ${ }^{* 15}$ 。外羅老島は昔から海老漁業の根抛地として知られており、1903年 に岡山県の小野鶴松が最初に移住して干し海老を製造し始め、1906年に は同じ岡山累から 3 戸の漁民が移住して以降、本格的に移住漁村がつく られた。小野は漁業だけではなく、外羅老島の開発のために様々な活動を 行ったことで知られる゙ ${ }^{* 16}$ 。その後、羅老島付近はイシモチと鮼の養魚場とし て有名となり、漁船と運搬船の一大根㧋地として韓国南海岸屈指の日本人 移住漁村として発展していくととなった。

1909 年の熊本県水産試験場業務工程報告の第3回韓海出漁指導試験 では、羅老島の当時の状況を次のように記述している。

“現地、明石町 ${ }^{* 17}$ に石油発動船、汽船…(中略)…など各出漁船60隻が停泊中で あり、飲食店12店などがある。…...*18

以降、1905年の「第2次日韓協約」と1910年の「韓国併合条約」を経て、 日本人の移住が增えるとともに沿岸部を埋め立て、近代的な漁港として発 展する。1917年の朝鮮総督府の陸地测量部作成の地形図 $(1: 50,000)$ を みると、現在筑亭 1 区と 2 区が接する付近に集落が構成されており、この付 近を中心として住居地が拡張したと推察される。さらに、上水道と電話を架 設し、そして自家発電所を設置して電気を送電するなど他の島㠗地域では 前例をみないものであっだ19。

ヒアリング調查によると、当時の日本人と韓国人の住み分けは比較的明 確である。筑亭1区と2区の境界を中心として、筑亭1区には主に韓国人が、 築亭2区には主に日本人が居住ことが明らかである。こうた海岸線沿いの 住み分けは他の日本人移住漁村と比べて極めて珍しい*20。

\section{3. 集落の空間構成}

日本植民地期につくられた日本人移住漁村の大半はその集落の規模と 関係なく、多様な機能的要素を持っているのが大きな特徵である。特に、 外羅老島港は韓国の他の著名漁港に比較して、規模(人口、面積など)は 極めて小さい漁村であったが、製氷所、製網所、造船所、缶詰工場などの 近代的な施設がつくられ、都市的な機能を有する漁業の生産・流通·商業 の一大センターであった。

\section{3-1 建物分布}

外羅老島の建物は住居、商業施設、公共施設、宗教施設、工業施設の 5つに大別される。（図2）建物の用途に着目してみると、外羅老島は以下 のような特徴を持つ。

1) 住居

住居は主に東西方向の旧本町通沿い(漁港の北端部)に密集しており、 他には街区内部に点在寸る程度である。北端部の敖地の住居は㹟い路地 沿いに有を奇せるように密集している反面、街区内部に点在する住居は背 後の小高い丘の地形に対応して階段状に構成されている。

2) 商業施設

商業施設は主に「し」型の海岸西端部の南北に通る道路に並行して並び、 その大半が1階に店舗、2階に住居を持つ店舗併用住宅である。他には漁 港の北端部に点在する。その機能としては、スーパー・マーケット、飲食店、 魚屋、船具店、雑货屋、宿泊施設、カラオケ、パン屋、喫茶店、クリーニン グ屋、薬局などがあり、その中で魚屋と飲食店が商業施設の約 5 割(商業 施設の92戸の内、47戸)を占めている。

3) 公共施設

主要な公共施設としては、面 ${ }^{* 1}{ }^{* 1}$ 事務所(役所)、警察署、鄄便局、金融機
関(銀行、相互金庫など)、消防署、医療施設、老人会館、予備軍本部"22、 公共倉庫、漁市場などがある。行政機関の大半は集落の入り口である東側 に集中している。特に、予備軍本部は新しい面事務所が1987年に建てられ て移転するまで面事務所として使われていた。機能は変化したものの、そ の建筑様式は現在も当時のままである。また、郵便局は集落の進入口あた り(調查対象S01)に1910年に開局されたが、1989年に現在の位置に移っ たものである。また現存しないが、漁業関連の行政施設として南端部に税 関があった。

4) 宗教施設

宗教施設としてはキリス卜教会が3つ、仏教寺院が1つある。キリス卜教会 はそれぞれ西端部の小高い丘、住居地の真中、北の河川の埋立地に位置 する。寺院は漁港の東の方に離れたところに設けられた。

一方、現存しないが、集落の背後の小高い丘の上に神明神社 ${ }^{* 3}$ が造ら れたといら事実がある。当時には小祠であったが、1945年に壊され、神社 に登る陼段と敷地、そして小祠の基碪の跡だけが残っている。

\section{5) 工業施設}

㴔港の南端部には工業施設が密集している。その種類としては造船所、 製水所、製網所、缶詰工場、醇造場など、主に漁業関連である。うした工 業施設の密集の背景には流通之商業の発展によって港湾面糟が足りなく なり、それまで整備されなかった南端部の磯の部分を埋立てられ、その敷 地に建物が集中した経緯がある。

\section{3-2 街区構成と街路体系}

現在、外羅老島の街路体系はら」字型の海岸道路、街区内の、海岸道 路に平行する旧海岸道路、そして住居地内部の海岸道路と直交する路地 の3つの道路が基盤となっている。日本植民地期当時の街路体系の軸とな る街区内の旧海岸道路は、海岸側が埋め立てられて海岸道路がつくられ たことによって、裏通り化された経緯がある。特に、屈曲された旧海岸道路 とそれに直交してつくられた路地によって、旧本町通に面した街区内の敷 地の形態は台形となるといら特徵がある゙ ${ }^{24}$ 。旧海岸道路は当時本町通と呼 ばれ、集落の主道路であった。

現在、裹通り化された旧本町通の幅は約 $3 \sim 4 \mathrm{~m}$ で、自動車は通れず、 歩行者専用道路のようになっている。また、旧本町通に直行する狭い路地 (平均幅約 1 3m) の形態は海岸方向には直線であり、山方向へは自然 地形をベースとして階段状の曲線である。旧本町通と路地の両側には石で つくられた側溝が現在も残っており、居住地背後の小高い丘から流れてく る水を海に排水している。

街区形態は、方形街区、台形街区、非定形街区の3つに分けられる。方 形街区は沿岸部が埋め立てられ、新しい住居地として形成された街区で、 格子状となっている。台形街区は、河口と海岸道路に接して比較的に平坦 な狭险地に位粗し、前述のような台形の敷地が並ぶ形態をとっている。特 に、山の迫った狭险地に形成された台形敷地は非定形住居地と接する場 合が多く、部分的に非定形の㪟地形態となる。非定形街区は丘陵地に位 置し、階段状になることが多く、形態は非定形でなる。台形街区は集合的な 観点からみると、方形街区と同様に連担しており、都市的な居住地形式で ある。

\section{3-3 居住地構造之街路景䚁}

外羅老島の居住地は東西に流れる河川と海が接したところに直交して形 成されており、全体の形は「し字のように曲がっている。居住地の真中には 旧本町通が通り，道路両側に連続して建物が並んでいる。東西につながる 河川沿いの道路には主に平屋と2階建ての住宅と店舗が、そして南北に通 

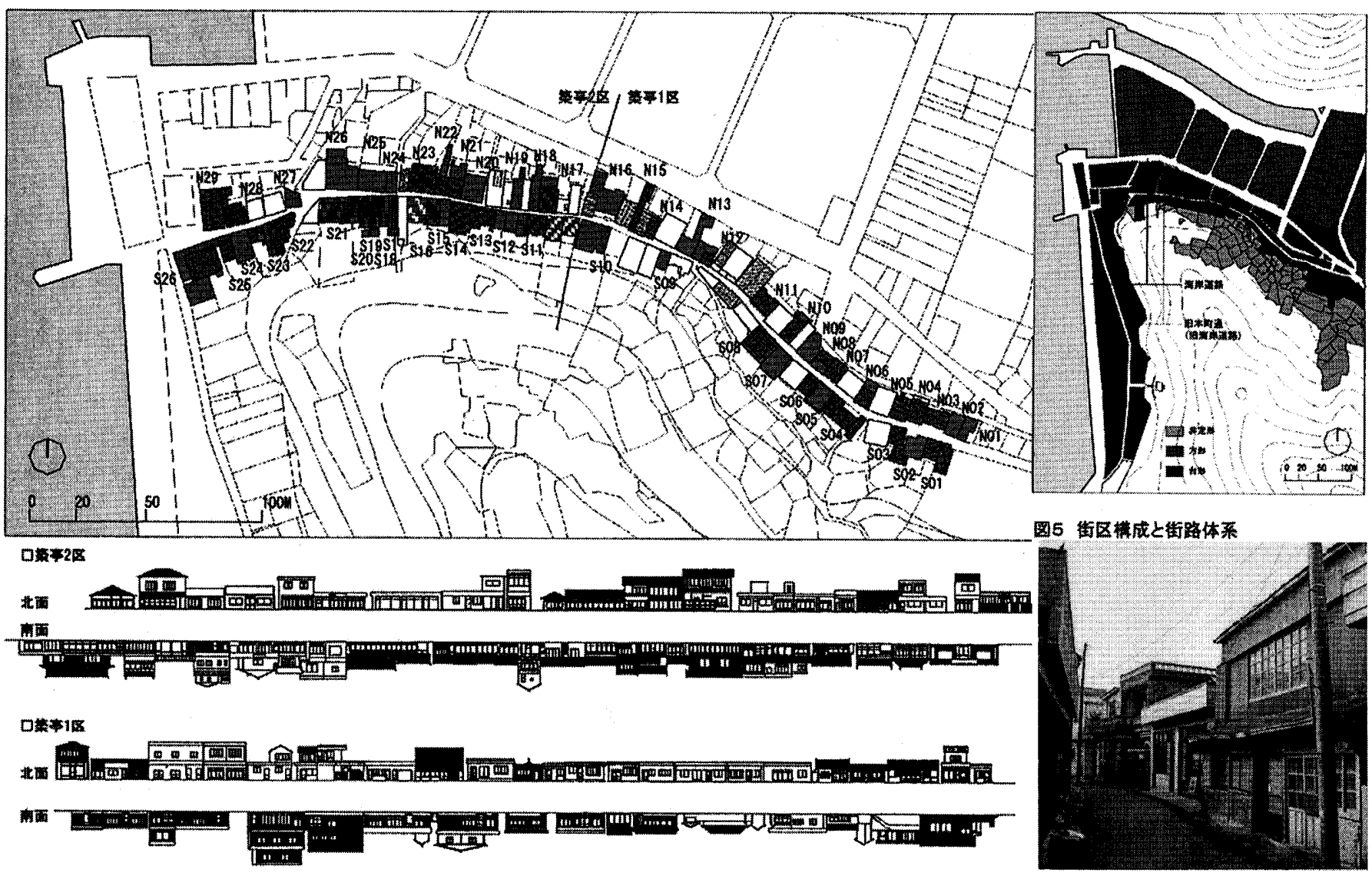

\section{図4 調查対象住宅と町並み}

る沿岸沿いには主に製水所、製網所、酸造場、缶詰め工場、造船所などの 比較的に規模が大きい漁業関連の建物がつくられている。

特に、調查対象地区である東西に走る旧本町通の町並みの規模は現在 でも当時と同様に維持されており、住宅と住宅は有を奇せるように壁を共有 した長屋となっているのが特徴である。建物が隙閒なく並ぶ街路風景を 構成しているのである。また、住宅は平入りが一般的で、全体的に水平的 な街路景観を持つ。現在、内部空間よりは外観を改造したものが多く、外 壁材料として赤レンガのタイルが数多く用いられている。

\section{4. 居住空間構成とその变容}

外羅老岛の旧本町通沿いの住宅の平面構成をみると、間口が狭くて奥 行きが長い短冊型が一般的である。また住宅の種類からみると、店舗併用 住宅より専用住宅が比較的多いといら特徴がある(調查対象の55棟の内、 28棟)。これは前述のように、旧本町通が裹通り化され、商業が衰退したこと に起因するものである。多くの店舗併用住宅が専用住宅に変容されたので ある。

\section{4-1 間口による類型}

旧本町通沿いの住宅の平面構成に見られる規則性を探るため、調查対 象の55棟の分類を試みた。住宅の閒取りの基本である柱間を間口に着目

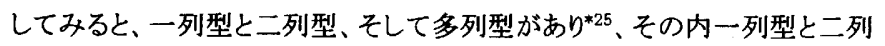
型が約6割以上(調查対象の55棟の内、38棟)を占めている。それぞれの 住宅類型の数は、一列型-14棟、二列型-22棟、多列型(別棟型を含む) ー19棟である。その類型を図7に示す。

間口の寸法は、二間(12尺、約 $3.6 \mathrm{~m})$ を基本としている。

一列型は、「二間」を基本とした、三尺の通路あるいは階段を付加する
「二間三尺(15尺、約 $4.5 \mathrm{~m}) 」 の$ 構成が一般的であり、内部空間は奥行き方 向に部屋が並ぶといら単純な構成を取っている。間取りは一列三室を基本 とし、「部屋(店舗)一台所一部屋」という極めて単純な構成を取っている。

二列型の間口は、一列型のほぼ2倍に当たる。その寸法を考察してみる と、「二閒十二間(24尺、約 $7.2 \mathrm{~m}) 」$ の構成が標準である。全体的な平面構成 は11)1階に居住空間の中心となる居間が設けられる、(2)台所やトイレなどの 水周り部分は主に教地の奥の方に設けられるといら2つの特徽がある。これ らの中には1945年以降に2棟の一列型の住居が統合され、二列型に改造 された事例(S12、N12)もある。また、1945年以降に新筑された事例にもこ のような間取りが多くみられ、狭い間口を持つ敷地の形態に起因寸るものと 推察される。多列型は、三列型が一般的である。2階の構成をみると、二間 を基本としているが、他に規則性は見当たらない。また、二列型と同様に一 列型と二列型が統合され、三列型となったものがある(S11、S14)。

以上から、間口に着目した類型分類を総合的に考察してみると、(1)外羅 老島の住宅は一列型と二列型が一般的であること、(2)一列型は一列三室 を基本とし、部屋-台所-部屋」といら極めて単純な構成であること、(3)二列 型の平面構成には1階にメイン空間として居間が設けられ、台所やトイレな どの水周り部分は主に教地の奥の方に設けられる傾向がみられること、とい う3つの特徵を指摘できる。

\section{4-2 奥行きによる類型}

前述のように外羅老島の旧本町通沿いの住宅の平面構成をみると、短 冊型が一般的である。こうした短冊型の住宅の空間構成を明らかにするた め、その典型的な類型である一列型を対象として奥行き方向の室の構成に 焦点を当てると以下のようになる。

一列型の住宅を奥行き方向に並ぶ部屋の数によって分類すると、一列 


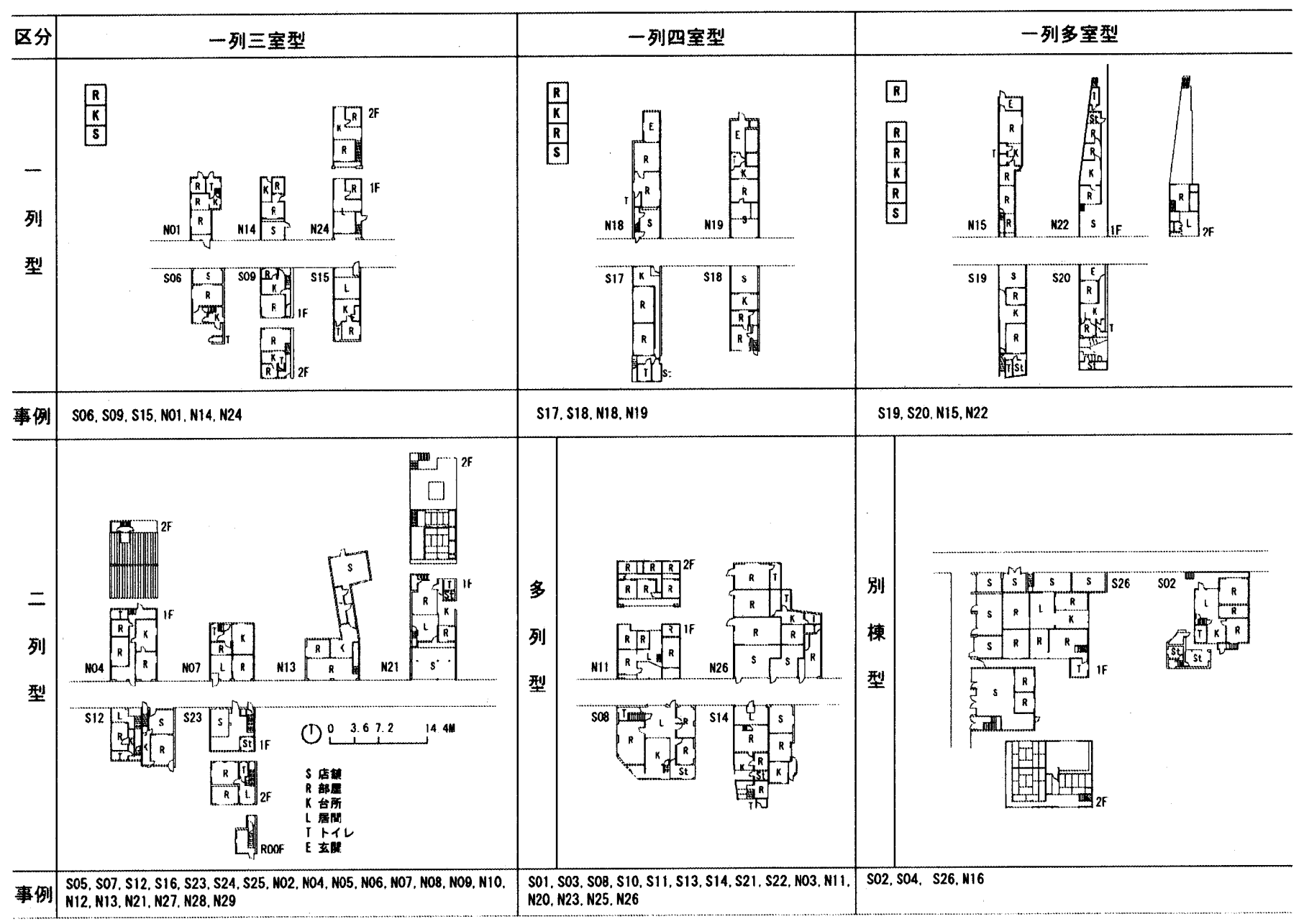

\section{図7 間口と奥行きによる分颣}

三室型、一列四室型、一列多室型の3つに分けられる。それぞれの数は一 列三茎型-6棟、一列四室型-3楝、一列多室型-5棟である。

一列三室型は、基本的に「部屋(店舗)一台所一部屋(トイレ)」といら極めて 単純な構成を取っている(S06、S09、S15、N01、N14、N24)。2階建て の場合には片面に奥行き方向に約 3 尺 $(0.9 \mathrm{~m})$ の階段を設けており、平 面構成は1階とほほ同様である。一列四室型は一列三室型に1つの室を 加えた形で、部屋(或いは店舗)一部屋一台所一部屋(トイレ)」または「部屋 (或いは店舗)一台所-部屋-部屋(トイレ)」といら構成が一般的である(S18、 N18、N19)。

一列多室型は敷地背後の余地があって增筑された場合 (S17、S19、S 20、N22) と背後に隣接する別の建物と統合された場合（N15）の2つの種 類がある。增筑や統合によって室の数は五室から七室まで增えるが、いず れにしても室の基本的な構成は一列三室型、一列四室型と変わらない。

\section{4-3 住宅の変容プロセスとその特性}

前稿林では、巨文島の日式住宅の增改築に一般的に見られる特徽とし て平面の拡張、室の統合による店舗面積の拡大、室の個室化の3つをあげ、 さらに建物そのものが統合あるいは分離されるプロセスを明らかにした。外 羅老島の住宅の增改築に一般的に見られる特徽は、巨文島の場合とあま り変わらない。しかし、外羅老身では2つの統合パターンがみられる。並列 して隣接するもの同志で統合される並列統合と背後に接するもの同志で統 合される直列統合である。その変容プロセスを図式化し、示すと図8のよう になる。

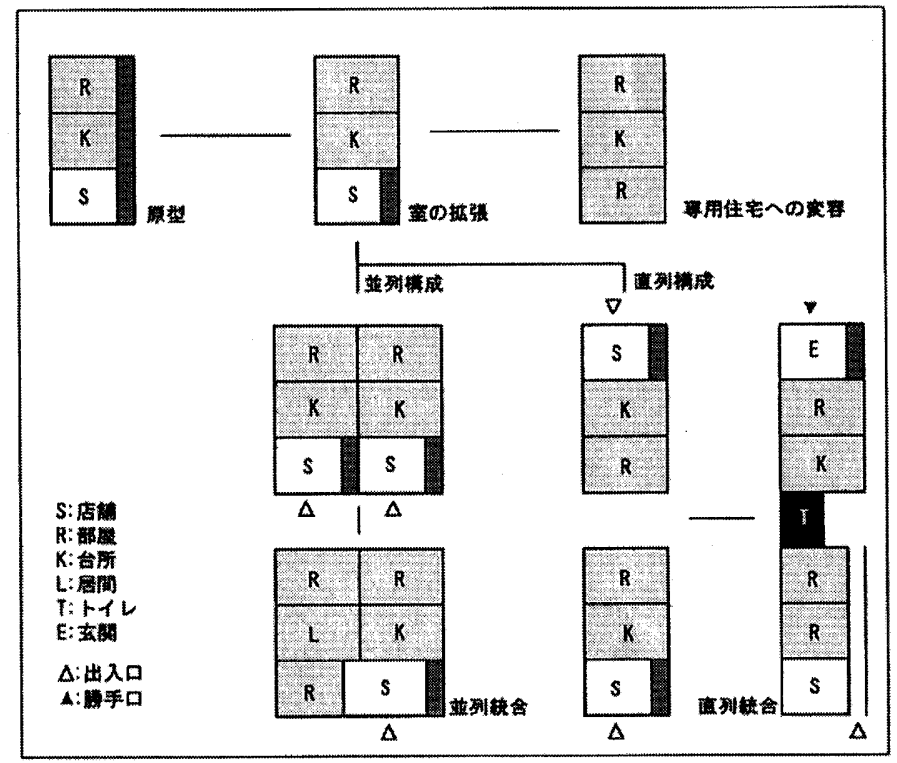

图8 並列䡚合と直列毓合のプロセス

並列統合は一列型が、2列に並んで隣接する壁の一部(特に2室目)を あけて二つの住宅を一つに統合するものである。並列統合には「一列型十 一列型 $\rightarrow$ 二列型」(S12、N12) と「一列型十二列型 $\rightarrow$ 三列型」(S11、S14)、 そして「一列型十一列型十一列型 $\rightarrow$ 三列型」(N26) といら3つの種類があ る。間口は「二間十二間 $(24$ 尺、 $7.2 \mathrm{~m}) 」 を$ 基本とし、外観は一つの建物の 
ように改造されているが、屋根の形は変わっていない。特に、二つの店赤 併用住宅が統合される時、表の一つの店舗は部屋に変わり、一つは店舗と して利用される。こうしたことによって店舗から変わった表の部屋には壁が つくられる。

直列統合は背後にある住宅と一つに統合されるもの(N13、N15)で、二 つの居住空閒を統合するため、その間に台所やトイレなどを設けるといら特 徵がある。内部空間構成の側面からみると、並列統合の事例より統合度が 高く、間取りも比較的変わっていない。

\section{5.まとめ}

本稿では、外羅老島の居住地の構造及び住居の空間構成とその変容に ついて以下の点を明らかにした。

(1)外羅老島の居住地構造は河川と海が接したところに直交して形成され ており、全体の形は「し」字形をしており、街路体系は海岸道路、それに平 行する街区内の旧海岸道路、そして海岸道路と直交する路地の3つの道 路が基盤となっている。

(2)これによって旧本町通に面した街区内の敷地の形態は台形となるとい う特徴がある。

(3)住宅の柱間を間口に着目して分類すると、一列型、二列型、多列型を 区別できるが、その内一列型と二列型が一般的である。特に短冊型の典型 的な類型である一列型は一列三室型を基本とし、「店舗一台所一部屋」という 極めて単純な構成を取っている。

(4)特に、短冊型は狭い間口を持つ数地の形態であるため、住宅の変容 特性として住居の統合がみられる。住宅の統合には並列統合と直列統合 の2つのパターンがみられる。並列統合は2列に並んで隣接する2つの住 宅の壁を一部あけて1つに統合するものであり、直列統合は背後の住宅と2 つに統合されるものである。

韓半島東海沿岸部に位置する日本人移住漁村に関する考察 ${ }^{* 27}$ は別稿 としたい。また、これまでの研究を踏まえた上で、離れ岛、河口、沿岸といっ た立地別居住地棬造、街区構成、居住空間構成とその変容などを比較・考 察したい。

\section{注}

*1 日本植民地期に㧍ける韓国の日本人移住漁村の形成と変容に関する研究は、

「日本住文化に韓国住文化」の2つを基軸に着目した文化変容の研究である。本稿は 韓国学術進興財団の〈国際協同研究〉鯟題である!韓国課題名; 韓国近代期浦口集 落の形成と変容に関する研究」(共同研究者; 布野修司·李勲·金泰永、2003年12月2004年11月)の一渨である。

*2 朴重信・布野修司、日本植民地における韓国の日本人移住漁村の形成に関する 研究一巨文島・巨文港を対象として、日本建策学会計画系諭文集、第577号、2004.3、 pp. $105-110$

*3 朴重信・布野修司、日本植民地期における韓国・巨文帛の日式住宅の空間栱成 と変容、日本建筑学会計画系論文集、第581号、2004.7、pp.55-60 *4 主要参考文献怯、在京蓬莱面郷友会の「蓬莱(羅老島)」(1988)、高興郡の「村由 来誌」(1991)、高興郡史編集委員会の「高興郡史 (上・下)」(2000)、清州大学建筑工 学部留猁建築研究室の「浦口集落実测調查報告書 15 (逢莱面・外羅老岛)」(2004)な どがある。

*5 日本人移住漁村の主要参考文献としては、吉田敬市の门朝鮮水産発達史」(1954)、 係禎睦の「日帝强占期都市化過程研究」(1996)がある。日式住宅の主要参考文献と しては、金泰永の「韓国開港期外人館の建築的特性に関する研究」(1991)、李㹂姫
の「韓国にある日式住宅の変遷とその影響に関する研究」(1993)、橴谷猛の「韓国に おける日本時代の住宅に関する研究一住宅関係法规を資料として」(1989)、川端貢 の「朝鮮住宅営団の住宅に関する研究」(1990)などがある。

*6 当時の海岸道路として、現在も集落の真中を通る主道路である。

*7 調查対象である東西方向の旧本町通沿いの住宅の数である。

*8 調查対象住戸はSO4、S14、S17、S18、S19、S20、S21、S22、N04、N10、N17、 N20、N21、N22の14棟である。

*9蓬莱といら地名は、この島に莲(よもぎ)が数多く咲くといら意味で名づけられた。 $* 10$ 羅老島の牧場はその周りが 30 余里 $(1$ 里 $=0.4 \mathrm{~km})$ で、馬を内羅老島に $139 匹 、$ 外 羅老島に119匹を養った。朝鮮英祖時代の記録によると毎年馬64匹と款草5,000束、 そして分誶馬を国に提供していた事塞がある。

*11 ヒアリング調查によると、羅老島」の表記に「老」を用いたのは、この地域が昔か ら海老漁業の根拋地であったことに起因する。

*12 漁業前進基地とは、給水施設、給油施設、共同合庫、漁業無線局などが設置さ れており、さらに漁獲物の処理·加工ができる多目的漁港を意味する。靼国では1966 年に巨文島、羅老島などの10力所を漁業前進基地として指定している。

*13「波市」とはその名前通り、海上で開かれる市場といら意味である。盛漁期には各 地域から集まった漁民によって船上で直接商売が行われた。

*14 日本人移住漁村の 27 所の集落を対象とし、形態に焦点を当ててみると、㴒型、 前島型、河川型に区分できる。朴重信·金泰水·本㘪、韓国近代期浦口集落の形成 過程と類型に関する研究、大韓建築学会春季学術発表大会諭文集、2004年4月、 pp. $543 \sim 546$

*15 在京蓬莱面鄉友会、蓬莱(羅老岛)、1988、pp.99-101

*16 当時、小野が死んでから神明神社の鏡内に功碑を立ててその業績を表した。清

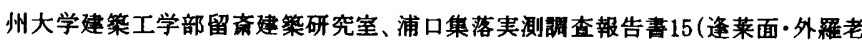
岛)、2004年8月、pp.12

*17 当時のこの地域の町名である。

*18 吉田敬一、朝鲜水産発達史、朝水会、1954、pp.269-270

*19 在京蓬莱面鄉友会、前揭書、pp.95-101

*20 日本人移住漁村の韓国人と日本人の住み分けを考察すると、主に海岸線沿い には日本人が、小高い丘には韓国人が居住することが一般的である。

*21 韓国における行政区域の単位で、日本の「村」に当る。

*22 予偏軍本部とは地域を防御するための地域守俏隊(軍隊)の本部を言う。

*23 ヒアリング調查によると、祭神として天照大御神を祭り、祭は毎年1月に行われた。 1940年頃に建てられたが、5年後の1945年に壤された経緯がある。

*24 朴重信·布野修司、前揭圇文(第577号、第581号)

*25 朴重信·布野修司、前揭諭女(第581号)

*26 朴重信·布野修司、前揭諭文(第581号)

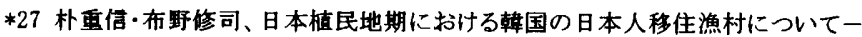
その3;九龍浦(グリョンポ)の事例、日本建筑学会大会学術講演梗概集、2004年8月、 pp. $709 \sim 710$

\section{主要参考文献}

[1] 吉田敬市、朝鮮水産発達史、朝水会、1954年

[2] 棌祯睦、日帝強占期都市化過程研究、一誌社、1996年

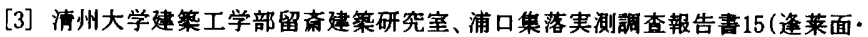
外羅老岛)、2004年8月

[4] 在京蓬莱面鄉友会、莲莱(羅老島)、在京莲莱面鄉友会、1988年

[5]高興郡史編集委員会、高興郡史(上·下)、高興郡史編集委員会、2000年

[6] 姜京男·金泰水、日本人移住漁村内一列型家屋の変容に関する研究-外羅老岛 の筑亭 1 -2区対象として、大韩建築学会秋季学術発表大会論文集、通巻24号·第2 号、2004年10月、pp.773-776

[7] 朝鮮総督府、朝鮮の聚落(前·中·後編)、朝鮮総督府、1933年

[8]李賢姬、靼国にある日式住宅の変遷とその影㗽に関する研究、漢陽大、1993年 [9] 都市住居研究会、異文化の葛藤と同化一韓国における「日式住宅、建策資料研 究社、1998年

[10] 安藤亮·近藤健雄、みなとまちの空間構成に関する研究、日本建築学会学術講 演会梗概集 (E-2)、1996年、pp.453-454 